\title{
Prediksi Angka Partisipasi Sekolah (APS) di Provinsi Banten dengan Menggunakan Interpolasi Lagrange
}

\author{
Nurhanifa ${ }^{1 *}$, Heni Pujiastuti ${ }^{2}$ \\ *e-mail: nurhaaniifa@gmail.com \\ ${ }^{1,2}$ Program Studi Pendidikan Matematika, Fakultas Keguruan dan Ilmu Pendidikan, \\ Universitas Sultan Ageng Tirtayasa
}

\begin{abstract}
School Participation Rate (APS) is a proportion of the number of school children at a certain level of education in the age group that is appropriate for the education network. This study aims to predict school participation rates for the next three years, so that these prediction numbers can be used as an alternative consideration for decision making for both the government and non-government directly related to education in order to improve the quality of education in Banten Province. In this study using a numerical method that is lagrange interpolation assisted by Matlab R2013a software to get predictive results of school participation rates (APS). From this study, after the APS prediction model is obtained, the next APS is predicted next three years after 2019. The prediction results obtained after the simulation are the school participation rates of 13-15 years old obtained prediction results for 2020, 2021 and 2022 respectively $96.76 ; 97.63$; and 98.51 . In the school participation rates aged 16-18 years obtained prediction results for 2020, 2021, and 2022 respectively 69.11; 69.51; and 69.90. It can be concluded that there has been an increase in school participation rates from previous years in Banten Province.
\end{abstract}

Keywords: School Participation Rate, Prediction, Lagrange Interpolation

\begin{abstract}
ABSTRAK
Angka Partisipasi Sekolah (APS) merupakan proporsi jumlah anak sekolah pada suatu jenjang pendidikan tertentu dalam kelompok usia yang sesuai dengan jejang pendidikan tersebut. Penelitian ini bertujuan untuk memprediksi angka partisipasi sekolah selama tiga tahun kedepan, sehingga angka prediksi ini dapat dijadikan sebagai alternatif pertimbangan pengambilan keputusan baik bagi pemerintah maupun selain pemerintah yang berkaitan langsung terhadap pendidikan demi terjadinya peningkatan mutu pendidikan di Provinsi Banten. Dalam penelitian ini menggunakan metode numerik yaitu interpolasi lagrange berbantuan software Matlab R2013a untuk mendapatkan hasil prediksi angka partisipasi sekolah (APS). Dari penelitian ini, setelah diperoleh model prediksi APS, maka selanjutnya diprediksi APS tiga tahun kedepan setelah tahun 2019. Hasil prediksi yang didapatkan setelah dilakukan simulasi yaitu pada angka partisipasi sekolah usia 13-15 tahun didapatkan hasil prediksi untuk tahun 2020, 2021, dan 2022 secara berturut-turut yaitu 96,76; 97,63; dan 98,51. Pada angka partisipasi sekolah usia 16-18 tahun didapatkan hasil prediksi untuk tahun 2020, 2021, dan 2022 secara berturut-turut yaitu 69,11; 69,51; dan 69,90. Dapat disimpulkan bahwa terjadi peningkatan angka partisipasi sekolah dari tahun-tahun sebelumnya.
\end{abstract}

Kata Kunci: Angka Partisipasi Sekolah (APS), Peramalan, Interpolasi Lagrange 


\section{PENDAHULUAN}

Pendidikan merupakan sektor yang memegang peranan penting bagi keberhasilan pembangunan suatu tempat. Pendidikan memberikan kontribusi secara langsung dalam pengembangan kualitas manusianya. Demi peningkatan mutu seluruh masyarakat perlu adanya upaya dalam bidang pendidikan baik dari pemerintah maupun masyarakatnya itu sendiri. Pendidikan didefinisikan sebagai upaya guna membangun kepribadian masyarakat yang sesuai pada nilai yang ada pada masyarakat dan budayanya (Sugianto, 2017).

$\begin{array}{rrr}\text { Perkembangan } & \text { suatu } & \text { wilayah } \\ \text { didukung kuat melalui mutu }\end{array}$
pendidikannya, semakin baik mutu pendidikan akan selaras juga dengan kemajuan suatu wilayah. Melihat urgensi pendidikan yang semakin diperlukan demi terciptanya pembangunan suatu bangsa, pemerintah telah menentukan kebijakan bagi siswa untuk wajib menempuh pendidikan 12 tahun mulai dari jenjang pendidikan dasar hingga pada jenjang pendidikan menengah.

Pemerataan Pendidikan menjadi hal penting untuk dilakukan. Naman, pada kenyataannya masih dapat ditemui anak-anak yang tidak melanjutkan sekolahnya. Berdasarkan data APS yang telah ada dapat mencerminkan kurangnya pemerataan pendidikan dimana sampai saat ini angkanya belum mencapai $100 \%$ (Arzelina et al., 2019).

Angka Partisipasi Sekolah (APS) didefinisikan sebagai rasio jumlah penduduk melek aksara (Suryana, 2007). Lebih lanjut APS adalah perbandingan jumlah anak pada kelompok usia dan jenjang tertentu yang menempuh pendidikan formal. APS dapat kita jadikan barometer dalam menentukan pemerataan pendidikan pada suatu daerah. Sehingga melalui APS dapat menunjukkan tingkat kemakmuran suatu wilayah, hal ini tentu akan berkaitan dengan penurunan tingkat kemiskinan (Karini, 2018).

Angka partisipasi sekolah tentu saja dipengaruhi oleh berbagai faktor seperti faktor perekonomian, fasilitas pendidikan, hingga pada faktor kesejahteraan keluarga. Tingkat kemampuan perekonomian akan mempengaruhi peningkatan APS pada suatu wilayah (Nirwana, 2013). Kegiatan pendidikan di sekolah sudah tentu membutuhkan biaya. Bagi beberapa warga belajar yang termasuk kedalam keluarga miskin tentu ini bukan lagi menjadi prioritas. Biaya ini yang menjadikan kelompok warga tersebut yang menjadi penghambat untuk dapat menempuh kegiatan pendidikan formal.

Semakin tinggi nilai APS suatu wilayah maka dapat kita katakan bahwa wilayah tersebut dapat dianggap berhasil dalam memberikan pemerataan layanan pendidikannya. Berdasarkan pemaparan yang telah diberikan, bahwa APS dapat kita jadikan sebagai parameter pemerataan pendidikan, untuk itu peramalan terhadap APS menjadi penting karena berdasarkan nilai APS dapat membantu pemerintah dalam menentukan kebijakan terkait layanan pendidikan guna meningkatkan mutu pendidikan bangsa.

Studi mengenai APS yang telah dilakukan diantaranya yaitu (Suryadarma \& Suryahadi, 2009) mengatakan bahwa angka partisipasi sekolah dipengaruhi oleh banyaknya sekolah yang dibangun juga kesejahteraan keluarga. (Arzelina et al., 2019) (Amaliah, 2015) (Karini, 2018) (Ummy Zulfa Rahmatin, 2017) mengatakan bahwa aspek kemiskinan dapat berpengaruh secara signifikan terhadap APS. Sedangkan (Listianawati \& Pascasarjana, 2012) mengatakan bahwa kemiskinan tidak memiliki pengaruh yang signifikan terhadap angka partisipasi sekolah. (Purwanto, 2010) 
mengatakan bahwa angka partisipasi dipengaruhi pula oleh rasio murid terdapat tenaga pengajar dan sekolah. (Khairunnisa et al., 2015) angka partisipasi sekolah dipengaruhi oleh kurang memadainya fasilitas sekolah.

Penelitian ini berfokus pada data angka partisipasi sekolah (APS) di Provinsi Banten. Provinsi Banten terdiri dari 8 (delapan) pemerintah kabupaten / kota, 4 di antaranya berbentuk pemerintahan kabupaten (Tangerang, Serang, Lebak, dan Pandeglang) dan 4 lainnya berbentuk pemerintahan kota (Tangerang, Tangerang Selatan, Serang dan Cilegon). Pada tahun data tahun terakhir yaitu tahun 2019 angka partisipasi sekolah pada anak usia 13 hingga 15 tahun sebesar 95,79 dan pada anak usia 16 hingga 18 tahun sebesar 68,72 .

Penelitian terkait angka partisipasi sekolah di Banten telah dilakukan oleh (Suwandana, 2018) menunjukkan bahwa perekonomian daerah kabupaten/kota di Provinsi Banten memiliki hubungan walaupun tidak terlalu signifikan dengan tingkat partisipasi sekolah SMA, namun tidak memiliki hubungan dengan tingkat partisipasi ke jenjang perguruan tinggi. Namun, belum ada penelitian yang membahas prediksi angka partisipasi sekolah di Provinsi Banten.

Studi mengenai metode numerik yang digunakan sebagai dasar dalam memperoleh angka prediksi sudah banyak dilakukan dalam berbagai pengaplikasian bidang ilmu. Seperti studi (Yulianto et al., 2016) yang melakukan peramalan terhadap penderita HIV dengan metode interpolasi lagrange. (Arifin et al., 2011) melakukan peramalan prediktor cuaca maritim dengan interpolasi lagrange berdasarkan logika fuzzy. (Ngf \& Sihombing, 2017) melakukan studi penggunaan metode Newton Gregory terhadap hasil produksi pertanian kelapa sawit. (Pangruruk \& Barus, 2018) melakukan prediksi terhadap harga saham dengan menggunakan Interpolasi Newton Gregory Mundur.

Melihat urgensi dari pemerataan pelayanan pendidikan yang dapat tercermin melalui peningkatan APS untuk itu studi APS perlu untuk dilakukan. Metode numerik yang digunakan pada penelitian ini yaitu metode numerik interpolasi lagrange berbantuan software Matlab2013a untuk mendapatkan hasil prediksi mengenai angka partisipasi sekolah dalam 3 tahun kedepan. Tujuan penelitian ini yaitu mendapatkan hasil prediksi untuk dijadikan sebagai alternatif pertimbangan bagi pemangku kepentingan dalam membuat kebijakan yang paling sesuai dengan kondisi dan gambaran untuk tahun-tahun yang akan datang. Kebijakan yang dihasilkan akan lebih terstruktur sehingga harapannya dapat meningkatkan mutu pendidikan di Provinsi Banten.

\section{BAHAN DAN METODE}

Pada penelitian ini sumber data yang digunakan bersumber dari Badan Pusat Statistik (BPS, 2015) yang sudah diolah juga disajikan yakni data Angka Partisipasi Sekolah (APS) dalam suatu jenjang pendidikan dalam kurun waktu lima tahun (2015, 2016, 2017, 2018, 2019). Data sekunder ini diakses melalui https://banten.bps.go.id/.

Perhitungan angka partisipasi sekolah dapat dilakukan menggunakan rumus (Karini, 2018). APS untuk usia 1315 tahun diperoleh dari perbandingan antara jumlah anak usia 13-15 tahun yang menempuh pendidikan formal dibagi dengan jumlah seluru anak usia 13-15 tahun dikalikan dengan $100 \%$. Sama halnya untuk APS usia 16-18 tahun yakni diperoleh dari perbandingan jumlah anak usia 16-18 tahun yang menempuh Pendidikan formal dibagi dengan jumlah 
seluruh anak usia 16-18 tahun dikalikan dengan $100 \%$.

Berdasarkan data sekunder yang diperoleh dari BPS Provinsi Banten tahun 2015 hingga 2019 yang diakses melalui situs Banten dalam Angka Provinsi Banten diperoleh data Angka partisipasi sekolah anak usia 13 hingga 15, dan 16 hingga 18 tahun di Provinsi Banten.

Tabel 1. Angka Partisipasi Sekolah Usia 13-15 Tahun Provinsi Banten 2013-2018.

\begin{tabular}{cc}
\hline Tahun & APS \\
\hline 2015 & 95.29 \\
\hline 2016 & 95.59 \\
\hline 2017 & 95.67 \\
\hline 2018 & 95.79 \\
\hline 2019 & 95.79 \\
\hline
\end{tabular}

Tabel 2. Angka Partisipasi Sekolah Usia 16-18 Tahun Provinsi Banten 2013-2018.

\begin{tabular}{cc}
\hline Tahun & APS \\
\hline 2015 & 66.73 \\
\hline 2016 & 67.00 \\
\hline 2017 & 67.77 \\
\hline 2018 & 68.35 \\
\hline 2019 & 68.72 \\
\hline
\end{tabular}

Pengolahan data penelitian dilakukan menggunakan windows 10 dan software Matlab R2013a, serta koneksi internet. Metode numerik yang digunakan untuk mendapatkan hasil prediksi angka partisipasi sekolah yaitu dengan metode numerik interpolasi lagrange. Berikut disajikan gambar berupa tahapan dalam penelitian melalui diagram alir (flowchart).

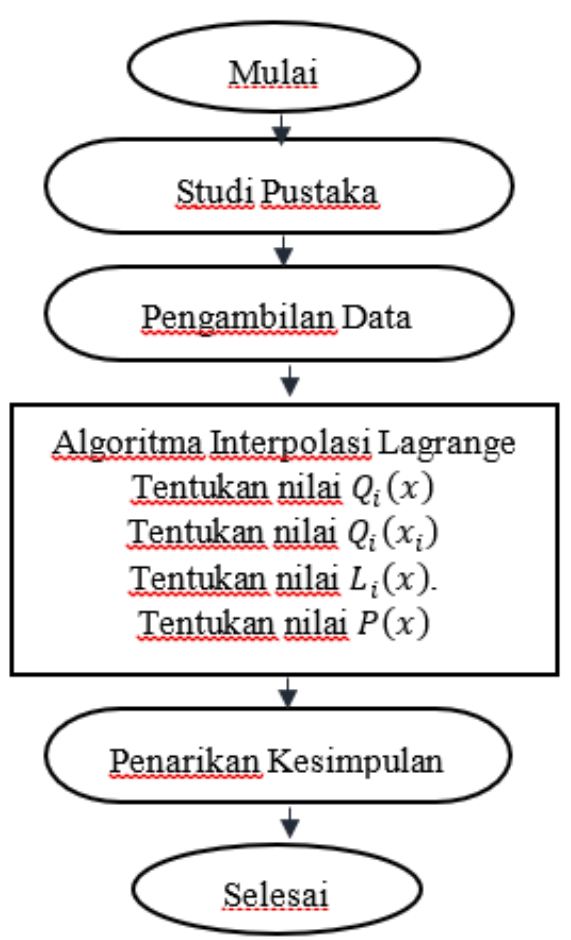

Gambar 1. Diagram Alir Tahapan Penelitian

Salah satu metode numerik yang paling dikenal yaitu Interpolasi Lagrange, karena fungsi yang digunakan pada interpolasi lagrange yakni bentuk polinom (Krisnawati, 2007). Interpolasi Lagrange digunakan untuk memperoleh fungsi polinomial berderajat tertentu yang melewati sejumlah titik data, maka dapat ditulis persamaan linearnya sebagai berikut:

(1) $y_{0}=a_{0}+a_{1} x_{0}$

(2) $y_{0}=a_{0}+a_{1} x_{1}$

Dan grafik dari persamaan (1) dan (2) disajikan dalam gambar berikut :

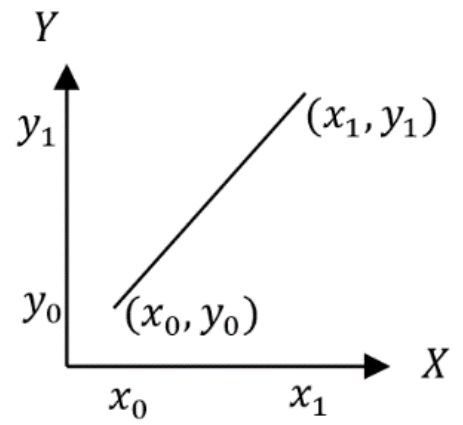

Gambar 2. Grafik Interpolasi Lagrange 
Kumudian , dari persamaan (1) dan (2) melalui proses aljabar akan diperoleh :

$$
a_{1}=\frac{y_{1}-y_{0}}{x_{1}-x_{n}}
$$

Jika dilakukan substitusi

(3) $\mathrm{ke}$ persamaan (1) maka diperoleh :

$$
\begin{aligned}
& y_{0}=a_{0}+a_{1} x_{0} \\
& a_{0}=a_{1} x_{0}-y_{0} \\
& a_{0}=\frac{y_{1}-y_{0}}{x_{1}-x_{n}} x_{0}-y_{0} \\
& a_{0}=y_{0}-\left(\frac{y_{1}-y_{0}}{x_{1}-x_{n}}\right) x_{0}
\end{aligned}
$$

Selanjutnya, lakukan substitusi persamaan (3) dan persamaan (4) kepada fungsi linear sehingga diperoleh :

$$
\begin{aligned}
f(x) & =a_{0}+a_{1} x \\
f(x) & =y_{0}-\left(\frac{y_{1}-y_{0}}{x_{1}-x_{0}}\right) x_{0}+\left(\frac{y_{1}-y_{0}}{x_{1}-x_{0}}\right) x \\
f(x) & =y_{0}+\left(\frac{y_{1}-y_{0}}{x_{1}-x_{0}}\right)\left(x_{1}-x_{0}\right) \\
f(x) & =\frac{y_{0} x_{1}-y_{0} x_{0}+y_{1} x-y_{1} x_{0}-y_{0} x+y_{0} x_{0}}{x_{1}-x_{0}} \\
& =\frac{y_{0}\left(x_{1}-x_{0}\right)+y_{1}\left(x-x_{0}\right)}{x_{1}-x_{0}} \\
& =\frac{\left(x_{1}-x_{0}\right)}{x_{1}-x_{0}} y_{0}+\frac{\left(x-x_{0}\right)}{x_{1}-x_{0}} y_{1} \\
& =\frac{\left(x-x_{1}\right)}{x_{0}-x_{1}} y_{0}+\frac{\left(x-x_{0}\right)}{x_{1}-x_{0}} y_{1} \\
& =L_{0}(x) y_{0}+L_{1}(x) y_{1}
\end{aligned}
$$

$$
P_{1}(x)=\sum_{i=1}^{1} L_{i}(x) y_{i}
$$

Persamaan (5) dapat disebut dengan polinomial Lagrange berderajat 1 . Sedangkan bentuk umum polinomial lagrange berderajat $\leq n$ untuk $(n+1)$ titik berbeda adalah :

$$
\begin{aligned}
& P_{1}(x)=\sum_{i=1}^{1} L_{i}(x) y_{i} \\
& P_{n}(x)=L_{0}(x) y_{0}+L_{1}(x) y_{1}+\cdots+L_{n}(x) y_{n}
\end{aligned}
$$

Dimana:

$L_{i}(x)=\prod_{i=0}^{n} \frac{x-x_{j}}{x_{i}-x_{j}}$ $L_{i}(x)=\frac{\left(x-x_{0}\right)\left(x-x_{1}\right) \ldots\left(x-x_{i-1}\right)\left(x-x_{i+1}\right) \ldots(x \text { diketahui diwakilkan oleh } n \text {, sehingga }}{\left(x_{i}-x_{0}\right)\left(x_{i}-x_{i}\right) \ldots\left(x_{i}-x_{i-1}\right)\left(x_{i}-x_{i+1}\right) \ldots\left(x_{i} \text { atg } 6 \text { rittma tadi bisa kita simpulkan }\right.}$

Berdasarkan prinsip interpolasi lagrange penulisan algoritma kasar dengan software Matlab2013a dapat dituliskan sebagai berikut (Krisnawati, 2007):

a. Menetapkan jumlah titik diketahui

Penginputan titik diketahui yaitu menggunakan dua buat array dengan aturan jumlah titik harus sama dengan jumlah data. Hal ini dimaksudkan untuk mempermudah dalam mengatur sifat data dalam program.

Alternatif lain dapat juga hanya menggunakan banyak array sebanyak jumlah titik diketahui, sehingga tiap data disimpan pada satu array. Namun, prilaku data, walau terkesan lebih sederhana. Dalam penelitian ini akan dipilih cara pertama yaitu dengan menggunakan dua buah array.

b. Menentukan nilai $L_{i}(x)$ dan $P(x)$

$L_{i}(x)$ diperoleh sejumlah titik yang diketahui, oleh karena itu dibutuhkan iteration yang banyaknya sesuai dengan jumlah titik diketahuinya. Sama halnya dengan $P(x)$ adalah jumlah hasil kali $y_{i}$ dengan $L_{i}(x)$, oleh karenanya dibutuhkan iteration dengan jumlah yang sama dengan cara menentukan nilai $L_{i}(x)$.

Dibutuhkan $Q_{i}(x)$ juga $Q\left(x_{i}\right)$ dalam menentukan $\left(L_{i}(x)\right.$. Iteration dibutuhkan lagi sebab $Q_{i}(x)$ adalah hasil kali $x-x_{i}$ sebanyak jumlah titik yang diketahui. Perlu deperhatikan bahwa $x-x_{i}$ tidak dihitung kembali pada hasil kali. Untuk itu proses hanya akan digunakan untuk nilai selain $\left(x-x_{i}\right)$. Setelah $Q_{i}(x)$ didapatkan melalui memasukkan nilai $x_{i}$ pada $Q_{i}(x)$ baru dapat dilakukan pencarian nilai $Q_{i}\left(x_{i}\right)$. Nilai $L_{i}(x)$ baru dapat dicari setelah $Q_{i}(x)$ juga $Q_{i}\left(x_{i}\right)$ diketahui. Kemudian langkah berikutnya menentukan nilai $P(x)$.

Misalkan jumlah titik yang sebagai berikut:

1. Masukkan nilai $n$

2. Dari $i$ sama dengan 1 sampai dengan $n$ dengan cara ini sulit untuk mengatur 
Masukkan titik ke $i$

3. Dari $i$ sama dengan 1 sampai dengan $n$

Tentukan nilai $Q_{i}(x)$

Tentukan nilai $Q_{i}\left(x_{i}\right)$

Tentukan nilai $L_{i}(x)$.

Tentukan nilai $P(x)$

\section{HASIL DAN PEMBAHASAN}

Hasil perhitungan peramalan Angka Partisipasi Sekolah khususnya pada jenjang sekolah menengah yaitu pada anak usia 13-15 tahun dan anak usia 16-18 tahun menggunakan metode numerik interpolasi lagrange dengan pengaplikasian algoritma pada software Matlab2013a diperoleh hasil sebagaimana pada tabel berikut:

Tabel 3. Hasil Simulasi Prediksi Angka Partisipasi Sekolah Usia 13-15 Tahun menggunakan Interpolasi Lagrange

\begin{tabular}{cc}
\hline Tahun & APS \\
\hline 2015 & 95.29 \\
\hline 2016 & 95.59 \\
\hline 2017 & 95.67 \\
\hline 2018 & 95.79 \\
\hline 2019 & 95.79 \\
\hline $\mathbf{2 0 2 0}$ & $\mathbf{9 6 , 7 6 0 6 9}$ \\
\hline $\mathbf{2 0 2 1}$ & $\mathbf{9 7 , 6 3 5 6 4}$ \\
\hline $\mathbf{2 0 2 2}$ & $\mathbf{9 8 , 5 1 0 5 9}$ \\
\hline
\end{tabular}

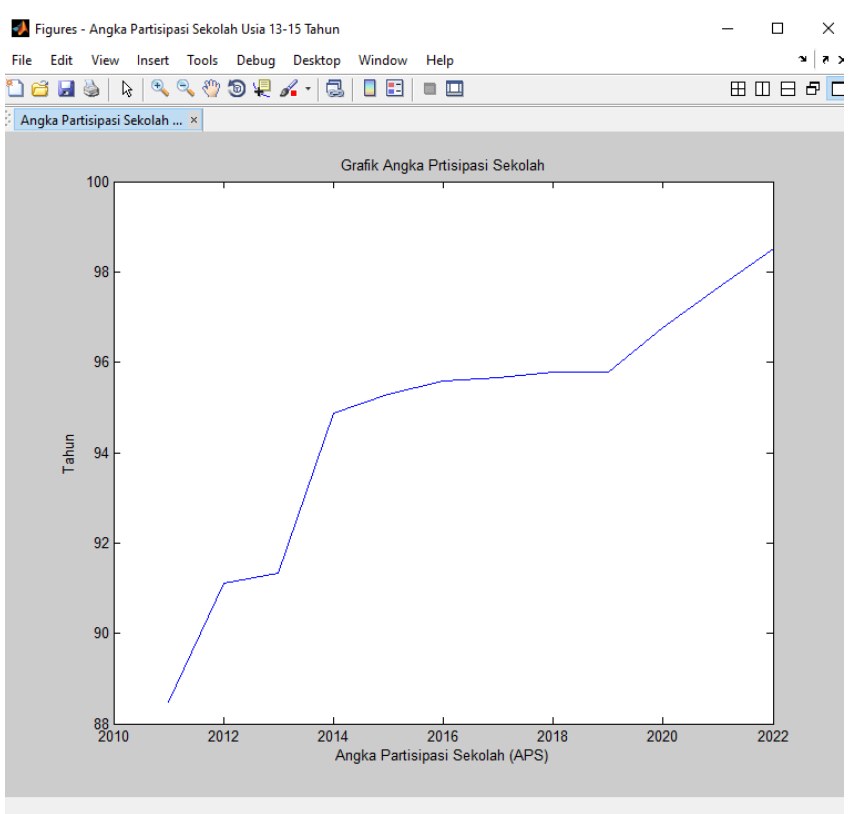

Gambar 3. Grafik Berdasarkan Software Matlab2013a pada APS Usia 13-15 Tahun.

Berdasarkan hasil prediksi angka partisipasi sekolah usia 13-15 tahun terdapat peningkatan angka. Pada prediksi pertama yaitu untuk tahun 2020 diperoleh angka prediksi sebesar 96,76; pada tahun 2021 diperoleh angka prediksi sebesar 97,66; pada tahun 2021 diperoleh angka prediksi sebesar 98,51. Hasil prediksi memperlihatkan bahwa pada angka partisipasi sekolah pada anak usia 13-15 tahun di Provinsi Banten terdapat peningkatan.

Tabel 4. Hasil Simulasi Prediksi Angka Partisipasi Sekolah Usia 16-18 Tahun menggunakan Interpolasi Lagrange

\begin{tabular}{cc}
\hline Tahun & APS \\
\hline 2015 & 66.73 \\
\hline 2016 & 67.00 \\
\hline 2017 & 67.77 \\
\hline 2018 & 68.35 \\
\hline 2019 & 68.72 \\
\hline $\mathbf{2 0 2 0}$ & $\mathbf{6 9 , 1 1 2 9 5}$ \\
\hline $\mathbf{2 0 2 1}$ & $\mathbf{6 9 , 5 0 5 4 5}$ \\
\hline $\mathbf{2 0 2 2}$ & $\mathbf{6 9 , 8 9 7 9 4}$ \\
\hline
\end{tabular}




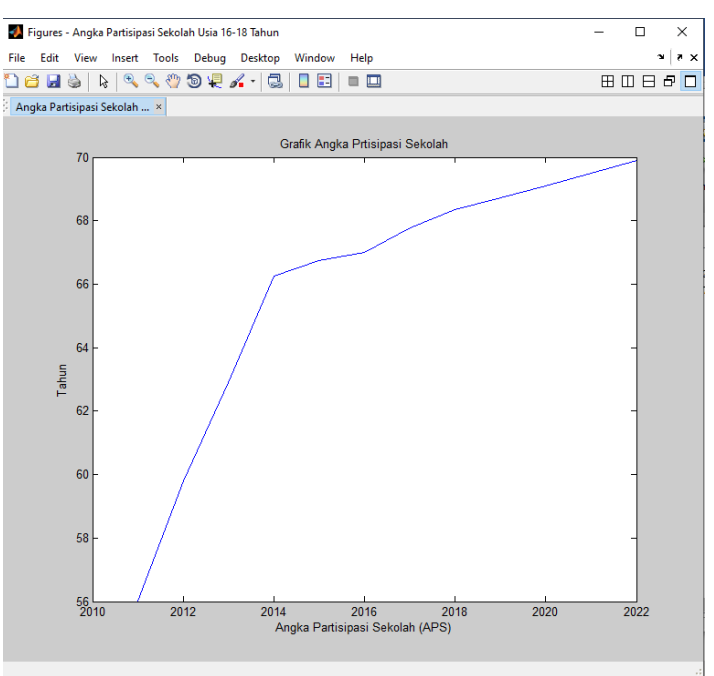

Gambar 4. Grafik Berdasarkan Software Matlab2013a pada APS Usia 13-15 Tahun.

Berdasarkan hasil simulasi prediksi angka partisipasi sekolah pada anak usia 16-18 tahun terdapat peningkatan angka. Pada prediksi pertama yaitu untuk tahun 2020 diperolah angka prediksi sebesar 69,11; pada tahun 2021 diperoleh angka prediksi sebesar 69,51; pada tahun 2022 diperoleh angka prediksi sebesar 69,90. Hasil prediksi memperlihatkan bahwa pada angka partisipasi sekolah pada anak usia 16-18 tahun di Provinsi Banten terjadi peningkatan.

Hasil ini sedikit berbeda dengan penelitian (Kharis et al., 2014) mengenai prediksi angka partisipasi sekolah namun dengan data berbeda dimana data yang dilakukan uji coba ialah data angka partisipasi sekolah Jawa Timur. Pada penelitian itu didapat bahwa prediksi angka partisipasi sekolah mengalami peningkatan dan penurunan untuk beberapa tahun kedepan. Sedangkan pada penelitian ini didapatkan hasil prediksi angka partisipasi sekolah di Banten terus mengalami peningkatan dalam beberapa tahun kedepan.

Melihat terjadinya peningkatan pada hasil prediksi angka partisipasi sekolah untuk anak usia 13-15 tahun dan anak usia 16-18 tahun. Angka yang dihasilkan pada usia 13-15 tahun relatif lebih tinggi dibandingkan dengan usia 16-18 tahun. Berdasarkan hasil prediksi yang telah didapatkan akan menjadi alternative sebagai bahan pertimbangan untuk pengambilan keputusan maupun kebijakan pemerintah dan atau lembaga terkait untuk dapat meningkatkan mutu pendidikan di Provinsi Banten.

\section{KESIMPULAN}

Berdasarkan hasil simulasi didapatkan peningkatan angka partisipasi sekolah pada usia 13-15 tahun dan 16-18 tahun. Pada kedua jenjang tersebut mengalami peningkatan untuk beberapa tahun yang akan datang walaupun peningkatannya relative kecil. Pada angka partisipasi sekolah usia 13-15 tahun didapatkan hasil prediksi untuk tahun 2020, 2021, dan 2022 secara berturut-turut yaitu 96,76; 97,63; dan 98,51. Pada angka partisipasi sekolah usia 16-18 tahun didapatkan hasil prediksi untuk tahun 2020, 2021, dan 2022 secara berturut-turut yaitu 69,$11 ; 69,51 ;$ dan 69,90. Angka prediksi ini dapat dijadikan sebagai alternatif pertimbangan bagi pemangku kepentingan dalam membuat kebijakan yang berkaitan langsung terhadap pendidikan demi terjadinya peningkatan mutu pendidikan di Provinsi Banten.

Saran untuk penelitian lebih lanjut dapat digunakan metode numerik lainnya seperti metode interpolasi newton Gregory, regresi linear, ataupun dengan permodelan matematika.

\section{DAFTAR PUSTAKA}

Amaliah, D. (2015). Pengaruh Partisipasi Pendidikan Terhadap Persentase Penduduk Miskin. Faktor Jurnal Ilmiah Kependidikan, 2(3), 231239.

Arifin, S., Aisjah, A. S., \& Hakim, J. Al. 
(2011). Interpolasi Lagrange dan Newton untuk peningkatan jangkauan ramalan prediktor cuaca maritim berdasarkan logika fuzzy, studi kasus:L di perairan Laut Jawa. Seminar Nasional Senta 2011, X1-9. Arzelina, E. S., Handajani, S. S., \& Zukhronah, E. (2019). Model Angka Partisipasi Sekolah Di Provinsi Jawa Tengah Menggunakan Regresi Data Panel. The 9 Th University Research Colloqium 2019 Universitas Muhammadiyah Purworejo.

BPS. (2015). Data Angka Partisipasi Sekolah Provinsi Banten. https://www.bps.go.id/

Karini, P. (2018). Pengaruh Tingkat Kemiskinan Terhadap Angka Partisipasi Sekolah Usia 16-18 Tahun Di Provinsi Kepulauan Bangka Belitung. Al-Ishlah: Jurnal Pendidikan, 10(1), 103-115.

Khairunnisa, K., Hartoyo, S., \& Anggraeni, L. (2015). Determinan Angka Partisipasi Sekolah SMP di Jawa Barat. Jurnal Ekonomi Dan Pembangunan Indonesia, 15(1), 91. https://doi.org/10.21002/jepi.v15i1.4 44

Kharis, R. M. R., Isnanto, R. R., \& Zahra, A. A. (2014). Prediksi Angka Partisipasi Sekolah Di Jawa Tengah Umur 16-18 Tahun Dengan Metode Jaringan Syaraf Tiruan PerambatanBalik. Transient, 3(1), 8-12.

Krisnawati. (2007). Implementasi interpolasi lagrange untuk prediksi nilai data berpasangan dengan menggunakan matlab. 2007(November), 1-7.

Listianawati, I., \& Pascasarjana, S. (2012). Faktor-Faktor yang Memengaruhi Pendidikan Dasar Di Sulawesi Utara.

Ngf, F., \& Sihombing, S. C. (2017). Prediksi Hasil Produksi Pertanian Kelapa Sawit di Provinsi Riau dengan Pendekatan Interpolasi Newton Gregory. 1999, 63-70.
Nirwana, I. D. (2013). Pengaruh Persentase Penduduk Miskin Pulau Jawa.

Pangruruk, F. A., \& Barus, S. P. (2018). Prediksi Harga Saham Dengan Interpolasi ISSN : 2502-6526 Book of KNPMP III 2018, 644-650.

Purwanto, D. A. (2010). Decentralization And Its Impact On Primary.Journal of Indonesian Economy and Business Volume 25, Number 1, 2010, $41-58,25(1), 41-58$.

Sugianto, E. (2017). Faktor Penyebab Anak Putus Sekolah Tingkat Sma Di Desa Bukit Lipai Kecamatan Batang Cenaku Kabupaten Inderagiri Hulu. JOM FISIP Vol. 4 No. 2 -Oktober 2017 Page 1, 4(2), 1-14.

Suryadarma, D., \& Suryahadi, A. (2009). The Contrasting Role of Ability and Poverty on Education Attainment: Evidence from Indonesia. November.

Suryana, S. (2007). Permasalahan Mutu Pendidikan Dalam Perspektif Pembangunan Pendidikan. Jurnal Partisipasi Sekolah.

Suwandana, E. (2018). Tingkat Partisipasi Sekolah dan Indikator Ekonomi Kabupaten / Kota di Provinsi Banten. 4, 20-23.

Ummy Zulfa Rahmatin. (2017). Pengaruh Tingkat Kemiskinan Dan Jumlah Sekolah Terhadap Angka Partisipasi Sekolah (Aps) Di Kota Surabaya. Pendidikan Ekonomi, 01(02), 105115.

Yulianto, T., Ulfaniyah, N. I., \& Amalia, R. (2016). Peramalan HIV Menggunakan Interpolasi Lagrange. Zeta - Math Journal, 2(1), 3-6. 